\title{
$\mathbf{Z}$ 型配位子の電子受容性を活用した金触媒反応の開発
}

\author{
村上 遼, 稲垣 冬彦*
}

\section{Development of Gold-catalyzed Reaction Utilizing Electron Acceptability of Z-type Ligand}

\author{
Ryo Murakami and Fuyuhiko Inagaki* \\ The Faculty of Pharmaceutical Science, Kobe Gakuin University; 1-1-3 Minatojima, Chuo-ku, Kobe 650-8586, Japan.
}

(Received August 20, 2020)

\begin{abstract}
The interaction between transition metals and ligands is important for catalytic reactions. The ligands are largely dominated by the covalent X-type (hydride, alkyl and halogen) and/or dative L-type ligands (e.g., P, N, CO, olefin, etc.). Therefore, the interaction of the $\mathrm{Z}$-type ligands $(\mathrm{B}, \mathrm{Al}$ and $\mathrm{Si}$, etc.) with transition metals is emerging as a new concept for the reactivity of the metal center. Recently, we developed the synthesis of the gold complex Au (DPB) X $(\mathrm{DPB}=$ diphosphine-borane) featuring the Z-type ligand, and their catalytic reaction. The gold catalysts showed a high activity compared to the general catalysts (without Z-ligand) for the various cyclization reactions due to the electronwithdrawing effect of the Z-ligand on the coordinating gold center. In this review, first the structure analysis of the synthesized $\mathrm{Au} \rightarrow \mathrm{Z}$ complex is introduced in detail, and second, the catalytic reactions based on the alkyne activation are described.
\end{abstract}

Key words — Z-type ligand; borane; gold; diphosphine-borane; catalytic reaction

\section{1.はじめに}

遷移金属触媒反応における配位子の効果は，その 触媒活性に大きく寄与するため重要である. Green らの定義に基づくと, 金属錯体の配位子は 3 種に分 類できる。 ${ }^{1)} 1$ つ目は，金属に対して 2 電子供与す る $\mathrm{L}$ 型配位子である。これら配位子はリンや窒素 電子，一酸化炭素，二重結合等が該当する (Fig. 1). 2 つ目は金属と配位子の間で共有結合性を有する X 型配位子であり，ハロゲンやアルキル，ヒドリド等 が挙げられる. 最後に, 空軌道を持つホウ素原子や アルミニウム，ケイ素等は，金属に対して 2 電子の 電子受容性を有する特徵を持ち, $\mathrm{Z}$ 型と呼ばれ る. ${ }^{2,3)}$ われわれの研究開始当初, 遷移金属触媒反応 に用いられる配位子の多くは，L 型若しくは X 型 配位子が用いられており， $\mathrm{Z}$ 型配位子を利用した遷 移金属触媒反応はほとんど知られていなかっ た. ${ }^{4-11)}$

電子受容性を持つ Z 型配位子は中心金属の電子

神戸学院大学薬学部分子薬学部門 ( 中央区港島 1-1-3)

*e-mail: finagaki@pharm.kobegakuin.ac.jp

本総説は, 日本薬学会第 140 年会シンポジウム S40 で

発表した内容を中心に記述したものである.

$$
\begin{aligned}
& \mathrm{M} \leftarrow: \mathrm{L} \quad \text { 2e donor } \quad \text { L-type ligand } \\
& \left.\mathrm{M}^{\cdot}\right\urcorner r^{\circ} \mathrm{X} \quad \text { le donor } \quad \mathrm{X} \text {-type ligand } \\
& \mathrm{M}: \rightarrow \mathrm{Z} \text { 2e acceptor } \begin{array}{c}
\mathrm{Z} \text {-type ligand } \\
\left(\mathrm{BR}_{3}, \mathrm{AlR}_{3}, \mathrm{SiR}_{4} \text {, etc. }\right)
\end{array}
\end{aligned}
$$

Fig. 1. Classification of Metal Ligands

密度を下げることができるため, 金属の Lewis 酸性 の向上が期待できる. 加えて, 酸化的付加・還元的 脱離が進行し易い金属種では, 酸化的付加の抑制が 可能となり，異なった反応形式をとることができ る, あるいは還元的脱離を促進する等の効果も挙げ られる.さらに，別種の Lewis 酸同士が近傍に存在 するため, $\mathrm{Z}$ 型配位子自体が Lewis 酸として機能 し，金属触媒との協働作用による多点認識型の反応 場を構築できると考えられる，以上の背景から，わ れわれは新規反応場の創出を目的とし， $\mathrm{Z}$ 型配位子 を有する金属錯体を用いた触媒反応研究を開始し た.ここでは，1） Z 型配位子を有する新規金錯体 の合成と構造解析，2）合成した金錯体を用いた触 媒反応, の 2 項目を順に紹介する.

\section{2. $\mathbf{Z}$ 型配位子含有金（I）錯体}

$\mathrm{Z}$ 型配位子及び金属はルイス酸として機能するた 


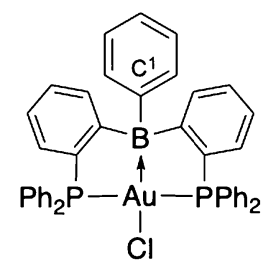

$\mathrm{Au}(\mathrm{DPB}) \mathrm{Cl}: 1$

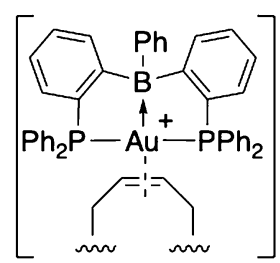

[Au(DPB) $\left.\mathrm{SbF}_{6}\right]_{2}$ (cod): 2
$\mathrm{SbF}_{6}^{-}$

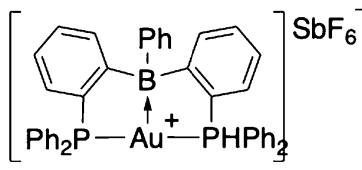

\section{Bourissou complex}

Cationic gold complexes

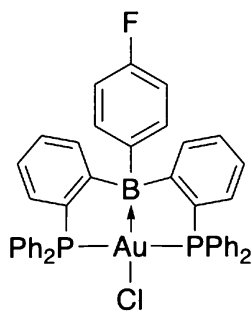

$\mathrm{Au}\left(\mathrm{DPB}^{\mathrm{F}}\right) \mathrm{Cl}: \mathbf{4}$

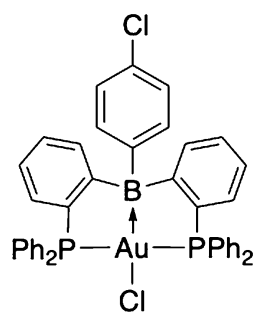

$\mathrm{Au}\left(\mathrm{DPB}^{\mathrm{Cl}}\right) \mathrm{Cl}: 5$

\section{Neutral gold complexes featuring electro-withdrawing group}

Fig. 2. Gold Complexes Featuring $\mathrm{L}_{2} / \mathrm{Z}$-type Ligands 1-5

め, 能動的に配位することは困難である，そのため， $\mathrm{L}$ 型配位子の近傍に Z 型配位子を導入した配位子 を設計することで “強制的に配位させる”手法が挙 げられる。 Bourissou らは近年，L型配位子として リン原子， Z 型配位子としてホウ素原子を有する monophosphine-borane (MPB), diphosphine-borane (DPB) , triphosphine-borane (TPB) の 3 種の配位子 の合成及びこれら Z 型配位子を有する遷移金属錯 体の合成を精力的に行っている. ${ }^{12-15)}$ 中でも, $\mathrm{Au}(\mathrm{DPB}) \mathrm{Cl} 1$ は合成が容易であり，空気中でも安 定であることが報告されていた。

そこでわれわれは，本錯体を起点とする金錯体 $\left[\mathrm{Au}(\mathrm{DPB}) \mathrm{SbF}_{6}\right]_{2}$ (cod) 216) を合成した (Fig. 2). 錯体 2 は, 溶液中で容易に cod が解離し, $\mathrm{Au}(\mathrm{DPB}) \mathrm{SbF}_{6}$ 3 へ変換可能である. 次に $\mathrm{Z}$ 型配位子の特性である 電子受容性を強くするため，ホウ素原子上のフェニ ル基のトランス位に電子吸引性基を導入した 2 種類 の金錯体 $\mathrm{Au}\left(\mathrm{DPB}^{\mathrm{F}}\right) \mathrm{Cl} \quad \mathbf{4 , 1 7 )} \mathrm{Au}\left(\mathrm{DPB}^{\mathrm{Cl}}\right) \mathrm{Cl} \quad \mathbf{5}^{17)}$ $\left[\mathrm{DPB}^{\mathrm{F}} ; \quad(p-\mathrm{F}-\mathrm{Ph})\left(o-\mathrm{Ph}_{2} \mathrm{PC}_{6} \mathrm{H}_{4}\right)_{2} \mathrm{~B}, \mathrm{DPB}^{\mathrm{Cl}} ; \quad(p-\mathrm{Cl}-\right.$ $\left.\mathrm{Ph})\left(o-\mathrm{Ph}_{2} \mathrm{PC}_{6} \mathrm{H}_{4}\right)_{2} \mathrm{~B}\right]$ を合成した（Fig. 2).

$\mathrm{Au}(\mathrm{DPB}) \mathrm{SbF}_{6} 3, \mathrm{Au}\left(\mathrm{DPB}^{\mathrm{F}}\right) \mathrm{Cl} 4, \mathrm{Au}\left(\mathrm{DPB}^{\mathrm{Cl}}\right) \mathrm{Cl} 5$ については X 線結晶構造解析を得ることができた (Fig. 3)。まず，力チオン性錯体 $\mathrm{Au}$ (DPB) $\mathrm{SbF}_{6} 3$ と中性錯体である $\mathrm{Au}(\mathrm{DPB}) \mathrm{Cl} 1$ との比較検討を 行った，金一ホウ素間の結合距離は，カチオン性錯
体 3 の方が，結合距離が長くなっていることが明ら かとなった．これは，カチオン性にすることで金中 心の電子密度が低下し，金-ホウ素間の相互作用が 弱まつたと考えられる. ${ }^{18)}$ また， Z 型配位子の電子 受容性については，金-ホウ素間の結合距離に反映 されると予想できる。そこで，合成した電子吸引性 基を持つ $\mathrm{Z}$ 型配位子含有金錯体 $\mathbf{4}, 5$ と既知である $\mathrm{Au}(\mathrm{DPB}) \mathrm{Cl} 1$ との比較検討を行った。 ハメットの 置換基定数 $\left(\sigma_{\mathrm{P}}\right)$ が $0(\mathrm{H}), 0.06(\mathrm{~F}), 0.22(\mathrm{Cl})$ と大 きくなるにつれて，金一ホウ素間の結合距離はわず かに縮まる (H: $2.335 \AA$ A F: 2.327 A, Cl: $2.321 \AA$ ) 結果が得られた. ${ }^{19,20)}$ 一方， ホウ素原子上フェニル 基イプソ位の炭素 $\mathrm{C}^{1}$-金原子間の距離に大きな変化 がみられた。 それは置換基定数が大きくなるにつれ て， $\mathrm{C}^{1}$ と金原子との距離が顕著に短くなり（H: $3.041 \AA$, F: $3.016 \AA, C l: 2.983 \AA$ ), 加えて $\mathrm{C}^{1}-\mathrm{B}-\mathrm{Au}$ の結合角も小さくなっている $\left(\mathrm{H}: 99.3^{\circ}, \mathrm{F}: 98.4^{\circ}\right.$, $\mathrm{Cl}$ ： 97.14º）ことが明らかとなった。この結果は, ホウ素原子上フェニル基の電子求引性が大きくなる ことで，金一ホウ素間だけでなく，金とフェニル基 上炭素 $\mathrm{C}^{1}$ との相互作用が高まり $\eta^{2}$ 型の配位状態と なっていることを示唆している. ${ }^{21,22)}$

\section{3. $\mathbf{Z}$ 型配位子を有する金触媒反応}

合成した Z 型配位子含有カチオン性金錯体は $\mathrm{Au}-\mathrm{B}$ 間の結合距離が減弱しているため，従来の金 


\begin{tabular}{|c|c|c|c|c|}
\hline & $\mathrm{Au}(\mathrm{DPB}) \mathrm{Cl} 1$ & {$[\mathrm{Au}(\mathrm{DPB})] \mathrm{SbF}_{6}: 3$} & $\mathrm{Au}\left(\mathrm{DPB}^{\mathrm{F}}\right) \mathrm{Cl} 4$ & $\mathrm{Au}\left(\mathrm{DPB}^{\mathrm{Cl}}\right) \mathrm{Cl} 5$ \\
\hline Hammett of $X\left(\sigma_{p}\right)$ & 0 & 0 & 0.06 & 0.22 \\
\hline$A \cup-B(A)$ & 2.335 & 2.521 & 2.327 & 2.321 \\
\hline$C^{1}-A u(A)$ & 3.041 & 3.102 & 3.016 & 2.983 \\
\hline$C^{1}-B-A u\left({ }^{\circ}\right)$ & 99.3 & 94.99 & 98.4 & 97.14 \\
\hline
\end{tabular}

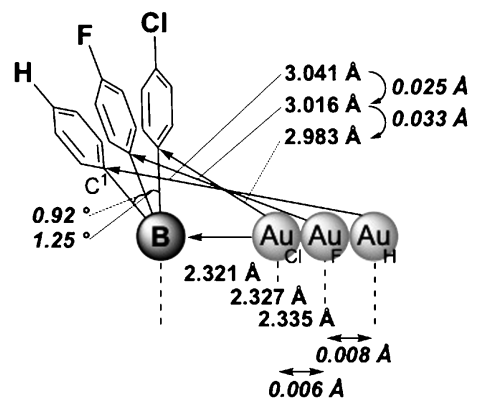

Fig. 3. Selected Bond Lengths and Angles in Experimental X-ray Data of 1, 3, 4, 5

Table 1. Cationic Au(I)-catalyzed Cycloisomerization of 1.6-Enyne 6

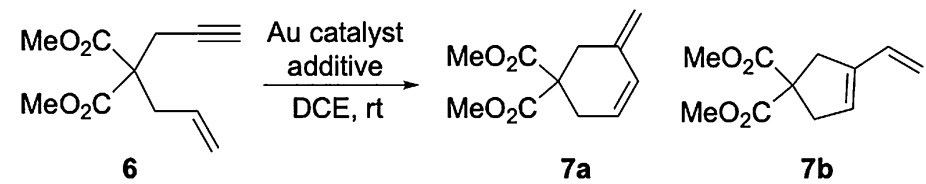

\begin{tabular}{|c|c|c|c|c|}
\hline Entry & Catalyst (mol\%) & atm. & Time & Result $(\mathbf{7 a}: \mathbf{7 b})^{\mathrm{a}}$ \\
\hline 1 & $\mathrm{Au}(\mathrm{DPB}) \mathrm{Cl} 1$ (2) & $\mathrm{Ar}$ & $24 \mathrm{~h}$ & no reaction \\
\hline 2 & $\mathrm{Au}(\mathrm{DPB}) \mathrm{Cl} 1(2)+\mathrm{AgSbF}_{6}$ & $\mathrm{Ar}$ & $<5 \min$ & $83 \%(6: 1)$ \\
\hline 3 & {$\left[\mathrm{Au}(\mathrm{DPB}) \mathrm{SbF}_{6}\right]_{2}(\mathrm{cod}) 2(1) \quad(2 \mathrm{~mol} \% \mathrm{Au})$} & $\mathrm{Ar}$ & $<5 \min$ & $99 \%(6: 1)$ \\
\hline 4 & {$\left[\mathrm{Au}(\mathrm{DPB}) \mathrm{SbF}_{6}\right]_{2}(\mathrm{cod}) 2(1)(2 \mathrm{~mol} \% \mathrm{Au})$} & air & $<5$ min & $99 \%(6: 1)$ \\
\hline 5 & {$\left[\mathrm{Au}\left(\mathrm{PPh}_{3}\right)_{2}\right] \mathrm{SbF}_{6}$} & air & $24 \mathrm{~h}$ & $9 \%(8: 1)^{b}$ \\
\hline 6 & {$\left[\mathrm{Au}\left(\mathrm{PPh}_{3}\right)\right] \mathrm{SbF}_{6}(2)$} & air & $10 \mathrm{~min}$ & $84 \%(6: 1)$ \\
\hline 7 & {$\left[\mathrm{Au}(\mathrm{DPB}) \mathrm{SbF}_{6}\right]_{2}(\mathrm{cod}) 2(1) \quad(0.4 \mathrm{~mol} \% \mathrm{Au})$} & $\mathrm{Ar}$ & $15 \mathrm{~min}$ & $98 \%(6: 1)$ \\
\hline 8 & {$\left[\mathrm{Au}\left(\mathrm{PPh}_{3}\right)_{2}\right] \mathrm{SbF}_{6}(0.4)$} & $\mathrm{Ar}$ & $24 \mathrm{~h}$ & no reaction \\
\hline 9 & {$\left[\mathrm{Au}\left(\mathrm{PPh}_{3}\right)\right] \mathrm{SbF}_{6}(0.4)$} & $\mathrm{Ar}$ & $10 \mathrm{~min}$ & $40 \%(2: 1)$ \\
\hline 10 & {$\left[\mathrm{Au}(\mathrm{DPB}) \mathrm{SbF}_{6}\right]_{2}(\mathrm{cod}) 2(1) \quad(0.4 \mathrm{~mol} \% \mathrm{Au})^{\mathrm{c}}$} & $\mathrm{Ar}$ & $15 \mathrm{~min}$ & $97 \%(6: 1)$ \\
\hline
\end{tabular}

a Ratio was determined by ${ }^{1} \mathrm{H}$ NMR. ${ }^{\mathrm{b}}$ SM 6 was recovered in $90 \%$ yield. ${ }^{\mathrm{c}}$ stored for 3 months at $\mathrm{rt}$ under air.

特有の三重結合親和性（alkynophilicity）を持つこ とが期待できる. ${ }^{23-36)}$ また三重結合が金に配位する ことで金中心の電子密度が高まり，ホウ素原子との 相互作用（電子受容性）が強くなることが予想でき る.これは三重結合の求電子性を向上させ，高い触 媒活性を示すのではないかと考えた，以上の仮説の 下，われわれは金触媒反応における， $\mathrm{Z}$ 型配位子含 有力チオン性金錯体の有用性を検証した，以下，順 に紹介する.

\section{3-1. エンイン化合物の環化異性化反応16) こ} れまでに，金触媒を用いたエンイン化合物の環化異 性化反応が数多く報告されている. ${ }^{37-43)}$ われわれは
$\mathrm{Z}$ 型配位子の電子受容性が触媒活性にどのような影 響を与えるか評価すべく，エンイン化合物 $\mathbf{6}$ を用い て触媒反応の検討を行った（Table 1)。最初に $2 \mathrm{~mol} \%$ の中性錯体 $\mathrm{Au}$ (DPB) $\mathrm{Cl} 1$ を用いて，アル ゴン雾囲気下， ジクロロエタン中室温条件下で 6 と 反応させたところ, 目的とする環化体 7 は全く得ら れなかった（Entry 1)。次に $2 \mathrm{~mol} \%$ の $\mathrm{AgSbF}_{6}$ を 添加し，カチオン性金錯体を系中で発生させた場合 では，環化体 7a，b が混合収率 83\%，6：1の比で 得られた (Entry 2)。これらの結果からカチオン性 金錯体が本触媒反応の活性種であることが明らかと なった。次に, $\left[\mathrm{Au}(\mathrm{DPB}) \mathrm{SbF}_{6}\right]_{2}(\mathrm{cod}) 2$ を用いて 
Table 2. Cationic Au(I)-catalyzed Cycloisomerization of 1,6- and 1,7-Enynes

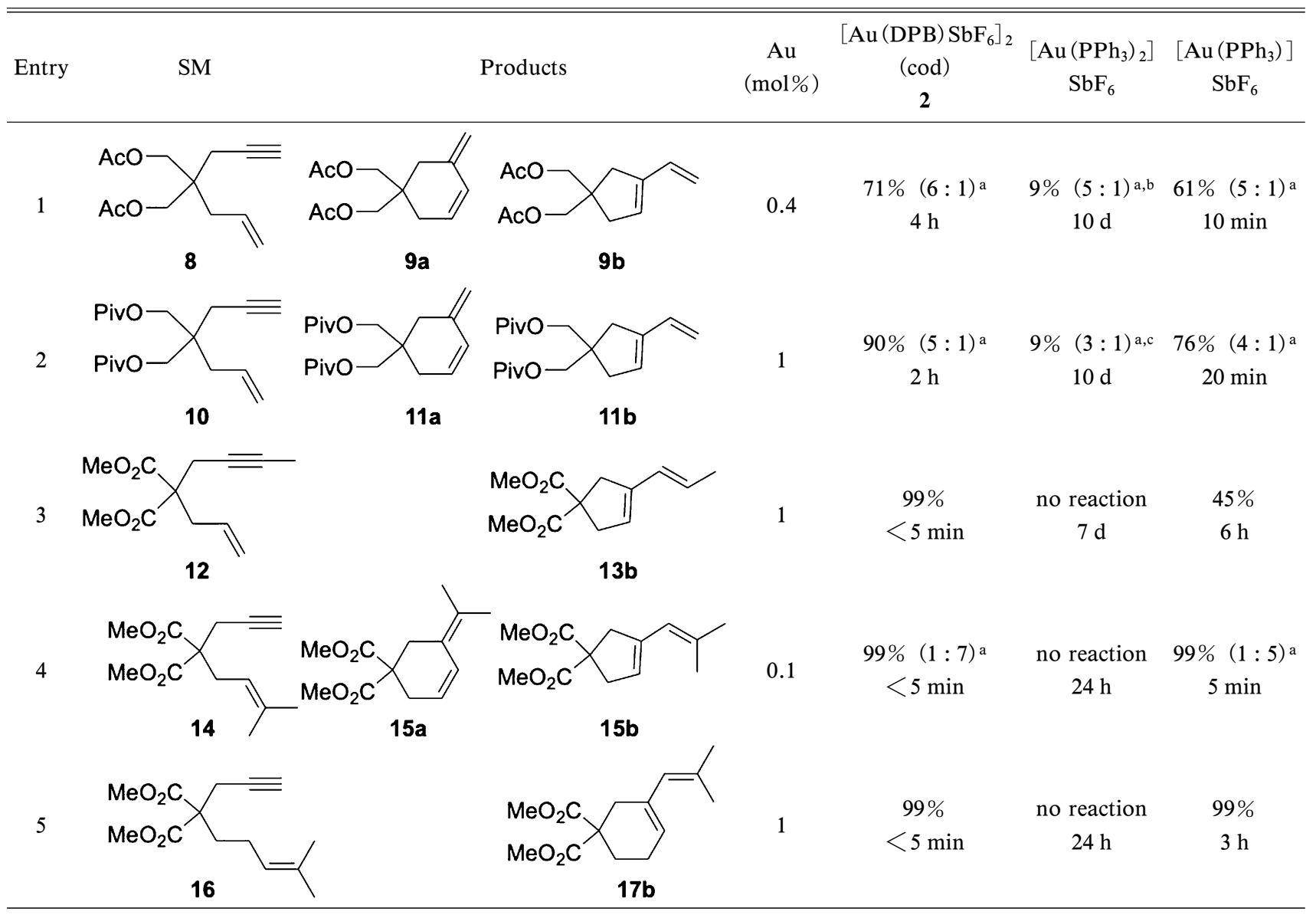

Reaction was carried out with a catalytic amount of $\mathrm{Au}(\mathrm{I}){ }^{+}$in $\mathrm{DCE}(0.1 \mathrm{M})$ at room temperature in air. Ratio of $\mathbf{a}: \mathbf{b}$ is in parenthesis. ${ }^{\mathrm{a}}$ Ratio was determined by ${ }^{1} \mathrm{H}$ NMR. ${ }^{\mathrm{b}} \mathrm{SM} 8$ was recovered in $76 \%$ yield. ${ }^{\mathrm{c}} \mathrm{SM} 10$ was recovered in $79 \%$ yield.

検討を行ったところ，収率は $99 \%$ ま向上した (Entry 3)。なお，本触媒を用いた検討では空気中 においても，同等の結果が得られた (Entry 4$)$ 。最 後に, 反応系内で $\mathrm{Z}$ 型配位子が機能しているかを 確認するため, $\mathrm{Z}$ 型配位子を持たない $\left[\mathrm{Au}\left(\mathrm{PPh}_{3}\right)_{2}\right]$ $\mathrm{SbF}_{6} や\left[\mathrm{Au}\left(\mathrm{PPh}_{3}\right)\right] \mathrm{SbF}_{6}$ と比較したところ，前者 ではほとんど反応は進行せず，後者では反応は進行 したものの, Entry 4 よりも若干劣る結果が得られ た（Entries 5,6)。また触媒量を $0.4 \mathrm{~mol} \%$ まで低 減したところ, $\left[\mathrm{Au}(\mathrm{DPB}) \mathrm{SbF}_{6}\right]_{2}(\mathrm{cod}) 2$ では同程 度の触媒活性を示す一方で, $\left[\mathrm{Au}\left(\mathrm{PPh}_{3}\right)_{2}\right] \mathrm{SbF}_{6}$ で は反応が全く進行しなくなり， $\left[\mathrm{Au}\left(\mathrm{PPh}_{3}\right)\right] \mathrm{SbF}_{6}$ で は 40\%まで収率が低下した（Entries 7-9）。なお, $\left[\mathrm{Au}(\mathrm{DPB}) \mathrm{SbF}_{6}\right]_{2}(\mathrm{cod}) 2$ は, 空気中室温下で 3 力 月保存していた触媒を用いても，遜色ない結果が得 られることからも長期保存が可能である (Entry 10).

質適用範囲と配位子の性能評価を行った（Table 2)。側鎖に異なる官能基を導入した基質 $\mathbf{8}, \mathbf{1 0}$ や内
部アルキン基質 $\mathbf{1 2}$ いずれにおいても Z 型配位子を 有する触媒 2 は，高い触媒活性を示し良好な収率で 目的物が得られた（Entries 1-3）。また，プレニル 基を持つ基質 14, 15 は, $\left[\mathrm{Au}(\mathrm{DPB}) \mathrm{SbF}_{6}\right]_{2}(\mathrm{cod}) 2$ と $\left[\mathrm{Au}\left(\mathrm{PPh}_{3}\right)\right] \mathrm{SbF}_{6}$ において同程度の結果が得られ た。一方で, $\left[\mathrm{Au}\left(\mathrm{PPh}_{3}\right)_{2}\right] \mathrm{SbF}_{6}$ は反応が全く進行 しなかった（Entries 6,7)。以上の結果から， $\mathrm{Z}$ 型 配位子含有カチオン性金錯体は， $Z$ 型配位子を持た ないものに比べ, 高い触媒活性と汎用性を示すこと が明らかとなった。

3-2. エンイン化合物の $[2+2]$ 環化付加反応 ${ }^{16}$

$\mathrm{Z}$ 型配位子含有力チオン性金触媒は, 従来の金触 媒よりも高い触媒活性を示した。 そのため，エント ロピー的に不利な 7 員環骨格を構築できるのではな いかと考えた。 そこで，エンイン化合物を用いた分 子内 $[2+2]$ 環化付加反応44-47)によるビシクロ [5.2.0] 環の構築を検討した. エンイン化合物 18 と $2 \mathrm{~mol} \%$ のカチオン性金触媒存在下, ジクロロエ夕 


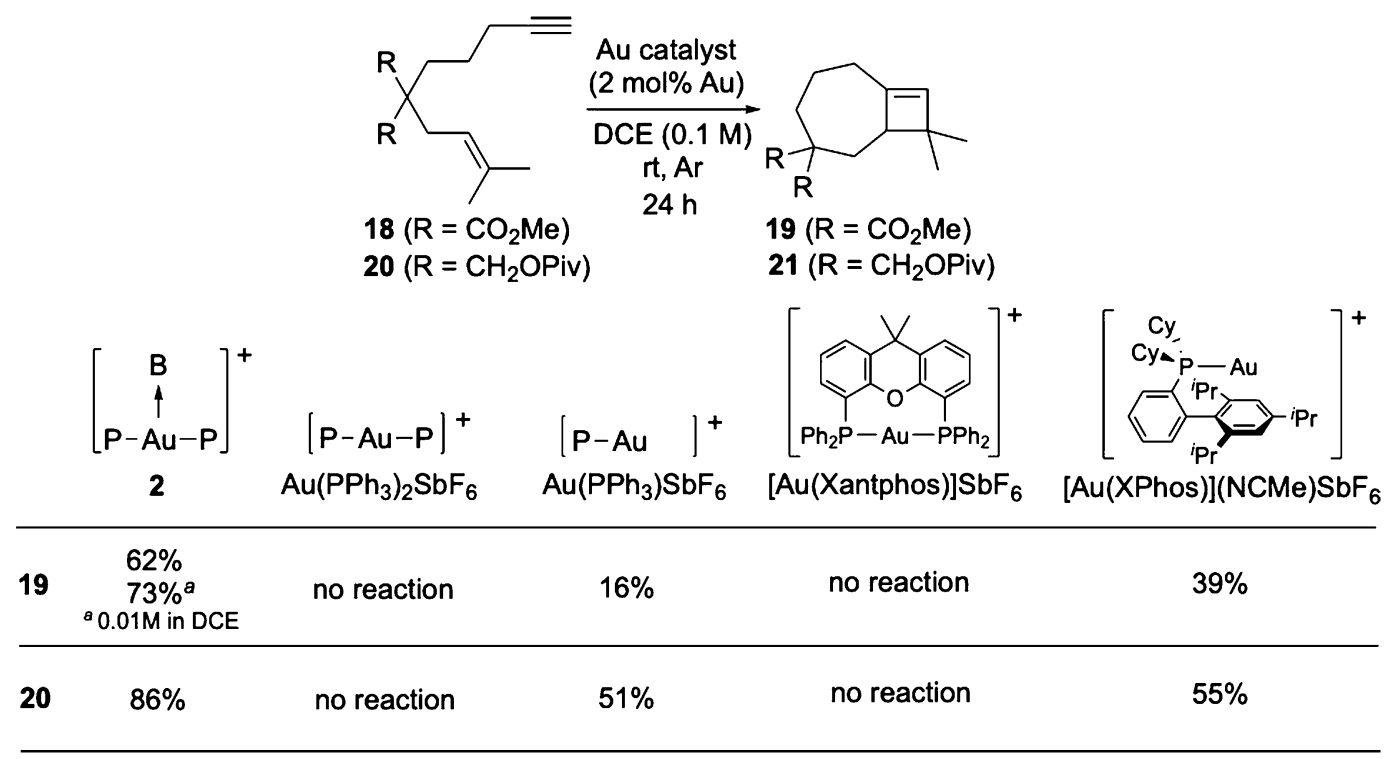

Scheme 1. Cationic Au(I)-catalyzed $[2+2]$ cycloaddition of 1,8-Enyne

ン溶媒中 $(0.1 \mathrm{M})$, 室温条件で反応を行った。 $\mathrm{Z}$ 型 配位子を有する $\left[\mathrm{Au}(\mathrm{DPB}) \mathrm{SbF}_{6}\right]_{2}(\mathrm{cod}) 2$ では，目 的とする環化体 19 が $62 \%$ の収率で得られ，希釈条 件下 $(0.01 \mathrm{M})$ においては，73\%まで収率が向上 した（Scheme 1)。一方， Z 型配位子を持たない $\left[\mathrm{Au}\left(\mathrm{PPh}_{3}\right)_{2}\right] \mathrm{SbF}_{6}$ や $\left[\mathrm{Au}\left(\mathrm{PPh}_{3}\right)\right] \mathrm{SbF}_{6}$ では, 反応 が全く進行しない若しくは低収率に留まる結果を与 えた。さらに Z 型配位子の代替として L 型配位子 を有する $[\mathrm{Au}$ (Xantphos) $] \mathrm{X}$ を用いた場合でも同様 に反応は全く進行しなかった。近年活発に研究され ているビアリール型配位子を持つ金触媒を検討した 結果，収率は中程度に留まった。また，側鎖 $\mathrm{R} に$ $\mathrm{CH}_{2} \mathrm{OPiv}$ 基を持つ基質 $\mathbf{2 0}$ においても類似の結果が 得られ， Z 型配位子含有力チオン性金触媒が最もよ い結果を与えた。

3-3. インージオール化合物の連続的 7-exo 環化 ${ }^{17)}$ われわれは多重結合活性化による炭素一炭素結合 形成反応において， $\mathrm{Z}$ 型配位子含有金触媒が高い触 媒活性を示すことを見い出した。 そこで，アルキン とへテロ原子との反応においても, 高い触媒活性が 発揮できるかどうかを検証した。 最初のアプローチ は，インージオール化合物の連続的環化反応であ る. 本反応はこれまでに金触媒による二環性の 5 員 環や 6 員環骨格の構築が報告されている. ${ }^{48-52)}$ 一方, 7 員環骨格の構築については報告されていなかった.

そこで， 7 員環構築を伴う環化反応への応用を試 みた（Table 3）。最初に，インージオール化合物 22
Table 3. Metal-Catalyzed Cyclization of Yne-Diol 22

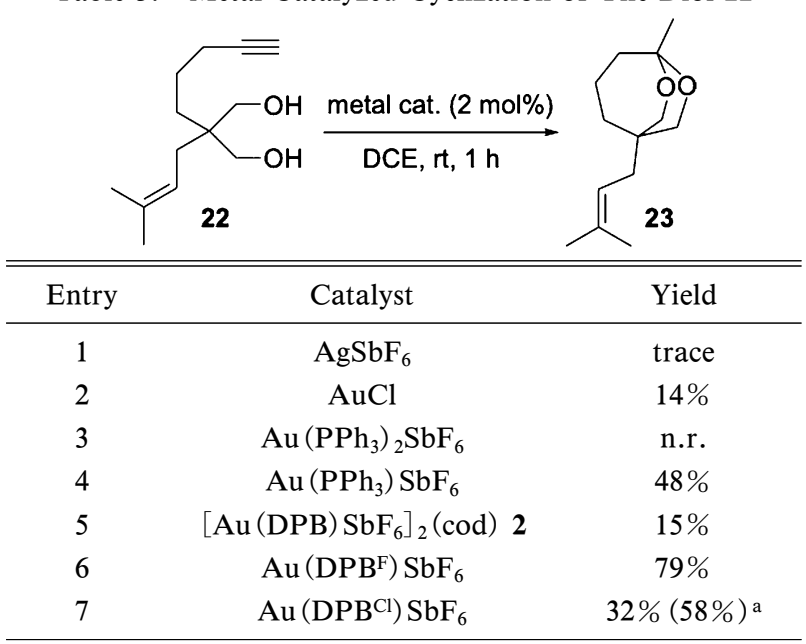

a Reacted for $48 \mathrm{~h}$.

に対し， $\mathrm{AbSbF}_{6}$ や $\mathrm{AuCl}$ を作用させた場合では, 環化体はわずかに得られる結果を与えた（Entries $1,2)$. 次に, $\mathrm{Z}$ 型配位子を持たない $\left[\mathrm{Au}\left(\mathrm{PPh}_{3}\right)_{2}\right]$ $\mathrm{SbF}_{6}$ や $\left[\mathrm{Au}\left(\mathrm{PPh}_{3}\right)\right] \mathrm{SbF}_{6}$ を本反応に適用したとこ ろ, 反応は進行しないか中程度の収率となった (Entries 3, 4). 一方で, $2 \mathrm{~mol} \%$ の $\left.\mathrm{Au}(\mathrm{DPB}) \mathrm{SbF}_{6}\right]_{2}$ (cod) 2 を作用させると目的とするジオキサビシク 口[3.2.2]誘導体 23 が低収率ながらも得られた (Entry 5)。次に，電子吸引性基を導入した $\mathrm{Z}$ 型配 位子を有する $\mathrm{Au}\left(\mathrm{DPB}^{\mathrm{F}}\right) \mathrm{Cl} 4$ と $\mathrm{AgSbF}_{6}$ から調製 した $\mathrm{Au}\left(\mathrm{DPB}^{\mathrm{F}}\right) \mathrm{SbF}_{6}$ を用いたところ，79\%まで収 率が向上した（Entry 6)。これは $\mathrm{Au}\left(\mathrm{DPB}^{\mathrm{F}}\right) \mathrm{SbF}_{6}$ が $\left[\mathrm{Au}(\mathrm{DPB}) \mathrm{SbF}_{6}\right]_{2}(\mathrm{cod}) 2$ よりも電子受容性が高 

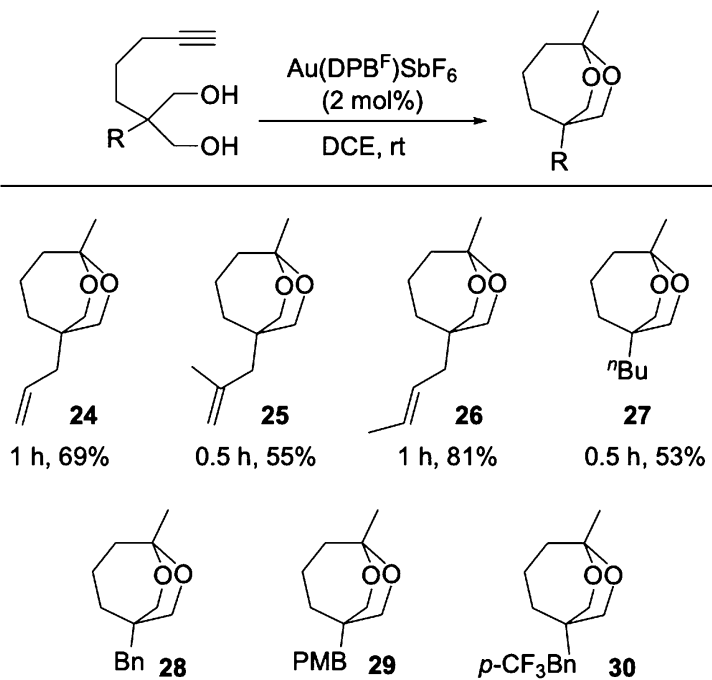

$1 \mathrm{~h}, 81 \%$

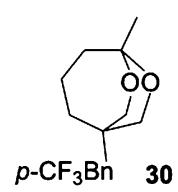

$1 \mathrm{~h}, 89 \%$

$1 \mathrm{~h}, 78 \%$

$1.25 \mathrm{~h}, 78 \%$

Scheme 2. Au (I)-catalyzed Cyclization of Yne-Diol

まっているため, 触媒活性が向上したと考えられ る.より高い電子求引性基を持つ $\mathrm{Au}\left(\mathrm{DPBCl}^{\mathrm{C}}\right) \mathrm{SbF}_{6}$ を用いた際，収率は 32\%まで低下した（Entry 7)。 遷移金属触媒反応は多段階反応を経るため，本結果 は金属の電子密度を低下させればかならずしも反応 活性が高まるのではなく，バランスが重要であるこ とを示唆している.

以上の検討において，良好な結果が得られた $\mathrm{Au}$ $\left(\mathrm{DPB}^{\mathrm{F}}\right) \mathrm{SbF}_{6}$ の条件を用いて，基質適用範囲を調査 した（Scheme 2)。まず，アリル基を有する基質で は反応が 1 時間で完結し，69\%の収率で目的とする 環化体 24 が得られた。また，1,1-二置換オレフィ ンやフェニルエチル基を有する基質においても同様 に反応は進行し，対応する環化体 25, 26 がそれぞ れ $55 \%$ と $81 \%$ 収率で得られた。次に，ブチル基を 側鎖に有する基質では，生成物 $\mathbf{2 7}$ の収率が $53 \%$ と なった。続いて，側鎖に $\mathrm{Bn}$ 基や $\mathrm{PMB}$ 基, $p-\mathrm{CF}_{3} \mathrm{Bn}$ 基を有する基質では，いずれも中程度から良好な収 率で目的の環化体 28, 29,30 を与えた。

3-4. アルキンの水和反応 ${ }^{53)}$ 官能基としてケ トンを形成する際，典型的な反応例の 1 つは，アル キンの水和反応である. 中でも三重結合へのオキシ 水銀化・脱水銀化は最も広く知られた反応である. しかしながら，優れた反応である一方で，水銀の高 い毒性が問題点として挙げられる。そのため, 金 ${ }^{54-70)}$ や白金, ${ }^{71)}$ ルテニウム, ${ }^{72,73)}$ 銀74,75) 等の代替 金属による水和反応が研究されている。一般的な金
Table 4. $\mathrm{Au}(\mathrm{DPB}) \mathrm{SbF}_{6}$-catalyzed Formal Hydration of Alkynes

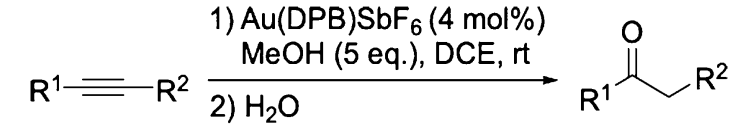

\begin{tabular}{|c|c|c|c|}
\hline Entry & Substrate & Product & Time Yield \\
\hline 1 & $\operatorname{PivO}_{31}()_{3}=$ & & 8 h $96 \%$ \\
\hline 2 & $\mathrm{HO}_{2} \mathrm{C}{ }_{33}^{(t)}=$ & & 43.5 h $92 \%$ \\
\hline 3 & $\mathrm { BnO } \longdiv { \overline { 3 5 } }$ & & $618 \mathrm{~h} \quad 55 \%$ \\
\hline 4 & $\mathrm{Ph}^{()_{27}}=$ & & $24 \mathrm{~h}$ \\
\hline
\end{tabular}

5<smiles>C#CCN1C(=O)c2ccccc2C1=O</smiles><smiles>C#Cc1ccc(OC)cc1</smiles><smiles>CC(=O)CN1C(=O)c2ccccc2C1=O</smiles><smiles>COc1ccc(C(C)=O)cc1</smiles>

触媒を用いた水和反応の例は，NHC 型金触媒存在 下， $50-120^{\circ} \mathrm{C}$ 程度の加熱条件で行われている．例 外として，Gatto らは，NHC 型金触媒を用いた 3-ヘキシンの水和反応が室温で進行していることを 報告している. ${ }^{63)}$ また，イソシアニド配位子を用い た金触媒では，アルキンの水和反応が室温で進行す ることが Xu らのグループが報告している. ${ }^{62}$

そこで Z 型配位子含有金触媒を用いれば，より 効率的な反応条件へ展開可能なのではないかと考 え，検討を行った（Table 4)。アルキン基質 $\mathbf{3 1}$ に 対し, $\mathrm{DCE}$ 中, $2 \mathrm{~mol} \%$ の $\mathrm{Au}(\mathrm{DPB}) \mathrm{SbF}_{6}$ と 5 当量 の $\mathrm{MeOH}$ を室温条件下で作用させた後，水で処理 したところ，対応する水和体 $\mathbf{3 2}$ が高収率で得られ た (Entry 1)。また，カルボン酸誘導体 $\mathbf{3 3}$ におい ても良好な収率でケトン $\mathbf{3 4}$ を得ることができた (Entry 2)。ベンジルオキシメチル，フェネチルな どで保護されたアミノプロピル基を有するアルキン 基質 35, 37, 39 においても，対応する生成物 36, 38, 40 をそれぞれ良好な収率で与えた（Entries 


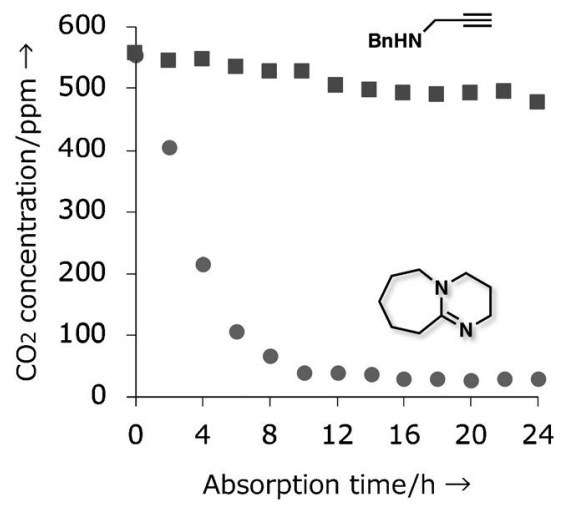

Fig. 4. The Ability of Propargylamine and DBU to Absorb Atmospheric $\mathrm{CO}_{2}$

3-5). 共役型アルキンである $p$-メトキシフェニル アセチレン 41 においても，87\%の収率で水和体 $\mathbf{4 2}$ が得られた (Entry 6)。

3-5. 大気中 $\mathrm{CO}_{2}$ を利用したオキサゾリジノン合 成 ${ }^{76)}$ 近年, $\mathrm{CO}_{2}$ を $\mathrm{C} 1$ 源とする触媒反応の開発 が活発になされており，その多くは高純度の $\mathrm{CO}_{2}$ ガスを用いている． $\mathrm{CO}_{2}$ 源として，大気中に含ま れている $0.04 \mathrm{vol} \%$ の $\mathrm{CO}_{2}$ を用いることが可能にな れば地球上どこででも容易に入手可能な炭素資源と なる。しかしながら，大気中 $\mathrm{CO}_{2}$ を利用した $\mathrm{CO}_{2}$ 固定化反応の開発は，その希薄さゆえか報告例は限 られている。このような背景の中，吉田らは2012 年に大気中 $\mathrm{CO}_{2}$ を活用した固定化反応を報告し た. ${ }^{77)}$ 本反応では，プロパルギルアミン誘導体に対 し，DMSO 溶媒中， $60^{\circ} \mathrm{C}$ の加熱条件下，触媒量の 硝酸銀と DBU を作用させると大気中 $\mathrm{CO}_{2}$ が反応 し，対応するオキサゾリジノン誘導体が得られるこ とを見い出している. 本反応は大気中の $\mathrm{CO}_{2}$ を固 定化できるため，非常に優れている。一方で，加熱 条件を必要とするため低エネルギー化の観点からも 室温化で反応が進行することが望ましい.

そこでわれわれは，吉田らの検証 ${ }^{77)}$ を参考に，室 温化を実現することにした．最初に，DBU 添加の 際にみられる反応加速効果の要因を調査することと し, 大気中低濃度 $\mathrm{CO}_{2}$ の吸収能力について検討し た（Fig. 4)。およそ $36 \mathrm{~L}$ の密閉空間内に $\mathrm{CO}_{2}$ 濃度 約 $600 \mathrm{ppm}$ の大気（およそ $1 \mathrm{mmol}$ の $\mathrm{CO}_{2}$ が含ま れる）を準備し， $5 \mathrm{mmol} の \mathrm{DBU}$ を静置してから 密封し，その空間内の $\mathrm{CO}_{2}$ 濃度を経時的に測定し た。空間内 $\mathrm{CO}_{2}$ 濃度は 6 時間経過の際， $100 \mathrm{ppm}$ 程度まで下がり，4 時間後では，ほとんど $\mathrm{CO}_{2}$ が
Table 5. The Carboxylation Reaction of Propargylamines 38 and Aerial $\mathrm{CO}_{2}$ at Room Temperature Using Catalyst of $\mathrm{Au}\left(\mathrm{DPB}^{\mathrm{F}}\right) \mathrm{SbF}_{6}$

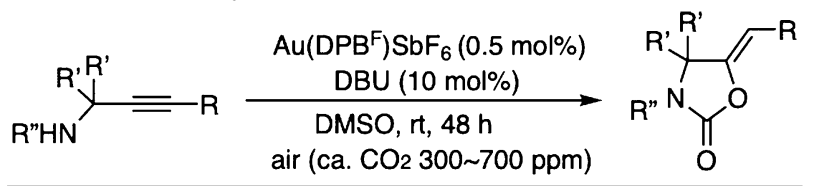

\begin{tabular}{llll}
\hline \hline Entry & Substrate & Product & Yield \\
\hline 1 & & &
\end{tabular}

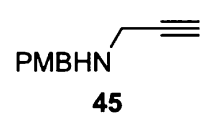

3

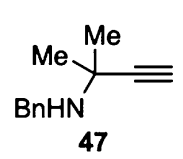

4

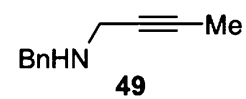

5

6

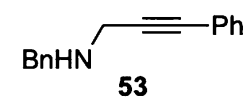

7

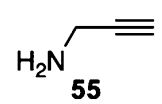

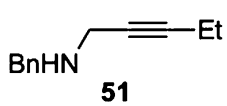

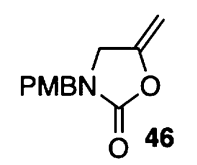

$60 \%$<smiles>C=C1OC(=O)N(Cc2ccccc2)C1(C)C</smiles>

$40 \%$<smiles>C/C=C1/CN(Cc2ccccc2)C(=O)O1</smiles>

$35 \%$<smiles>C/C=C1/CN(Cc2ccccc2)C(=O)O1</smiles>
$44 \%$<smiles>O=C1O/C(=C\c2ccccc2)CN1Cc1ccccc1</smiles>
$46 \%$<smiles>C=C1CNC(=O)O1</smiles>

残存しない結果を与えた。一方，同条件下，基質の プロパルギルアミン誘導体を用いた際，吸収はわず かしか観測されなかった。このことから，吸収性の 低い基質への $\mathrm{CO}_{2}$ の添加を，DBUがアシストして いることが予想される.

本触媒反応は，1）アミンと $\mathrm{CO}_{2}$ によるカルバミ ン酸形成，2）アルキンーカルバミン酸の環化反応の 2 段階で進行することが予想できる。前者は DBU 添加により加速していると考えられる，つまり，後 者の過程において加熱条件が必要かつ律速段階であ ることが示唆される。そこでわれわれは， $\mathrm{Z}$ 型配位 
子を有する金触媒の高い三重結合親和性の効果によ り，温和な条件下で本触媒反応が進行することを期 待して検討した（Table 5).

プロパルギルアミンのアミン部位をベンジル基で 保護した基質 $43\left(\mathrm{R}, \mathrm{R}^{\prime}=\mathrm{H}, \mathrm{R}^{\prime \prime}=\mathrm{Bn}\right)$ に対して大気 中存在下， $\mathrm{Au}\left(\mathrm{DPB}^{\mathrm{F}}\right) \mathrm{SbF}_{6}$ を作用させると室温条 件において目的の環化体 $\mathbf{4 4}$ が 90\%の高収率で得ら れることを見い出した (Entry 1)。アミン上に PMB 基を有する基質 $\mathbf{4 5}$ は， $60 \%$ の収率で対応す る環化体 46 が生成した（Entry 2)。また，プロパ

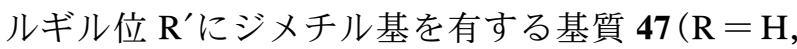
$\left.\mathrm{R}^{\prime}=\mathrm{Me}, \mathrm{R}^{\prime \prime}=\mathrm{Bn}\right)$ を用いた際，中程度の収率で目 的とする環化体 $\mathbf{4 8}$ が得られた。 さらにアルキン末 端 $\mathrm{R}$ にメチル基やエチル基，フェニル基を有する 基質 49, 51, 53 においても，それぞれ対応する環化 体 50, 52, 54 を与えた。一方，一級アミンを持つ基 質 $\mathbf{5 5}$ を用いた場合には反応性が大きく低下し，低 収率となった (56: 4\%)。

\section{4. おわりに}

本稿では，電子受容性を有する Z 型配位子から なる金錯体の性質を解明すべく，Z 型配位子含有金 錯体の合成とその構造，及び種々の触媒反応への適 用について述べてきた。これらの結果から， $\mathrm{Z}$ 型配 位子含有金触媒は， $\mathrm{Z}$ 型配位子を持たない触媒に比 べ，種々の触媒反応において高い触媒活性を示すこ とが明らかとなった。これは，Z 型配位子の電子受 容性が隣接金属の電子密度を低減させ，金属の Lewis 酸性が向上したためであると考えている。ま た Z 型配位子の中心金属への電子的影響は，他の 配位子とは明らかに異なるため，今後はこの反応場 を利用した新反応の開発へと展開していきたい.

謝辞本稿の研究成果は, 当研究室及び旧金沢 大学薬学系精密分子構築学研究室所属学生諸氏のた ゆまぬ努力によって発展を遂げてきたものであり， 深く感謝いたします。また，本研究の一部は，文部 科学省, 日本学術振興会, 科学技術振興機構 (JST) の支援を受けて行われたものであり，関係諸機関に 深く感謝いたします。

利益相反＼cjkstart開示すべき利益相反はない.

\section{REFERENCES AND NOTES}

1) Green M. L. H., J. Organomet. Chem., 500, 127-148 (1995).

2) Braunschweig H., Dewhurst R. D., Dalton Trans., 40, 549-558 (2011).

3) Amgoune A., Bourissou D., Chem. Commun., 47, 859-871 (2011).

4) Conifer C. M., Law D. J., Sunley G. J., White A. J. P., Britovsek G. J. P., Organometallics, 30, 4060-4066 (2011).

5) Malacea R., Saffon N., Gómez M., Bourissou D., Chem. Commun., 47, 8163-8165 (2011).

6) Anderson J. S., Rittle J., Peters J. C., Nature, 501, 84-87 (2013).

7) Smirnova E. S., Echavarren A. M., Angew. Chem. Int. Ed., 52, 9023-9026 (2013).

8) Yang H., Gabbaï F. P., J. Am. Chem. Soc., 137, 13425-13432 (2015).

9) Lin T.-P., Gabbaï F. P., Polyhedron, 125, 1825 (2017).

10) Jones J. S., Gabbaï F. P., Chem. Eur. J., 23, 1136-1144 (2017).

11) You D., Gabbaï F. P., J. Am. Chem. Soc., 139, 6843-6846 (2017).

12) Sircoglou M., Bontemps S., Mercy M., Miqueu K., Ladeira S., Saffon N., Maron L., Bouhadir G., Bourissou D., Inorg. Chem., 49, 3983-3990 (2010) .

13) Bontemps S., Gornitzka H., Bouhadir G., Miqueu K., Bourissou D., Angew. Chem. Int. Ed., 45, 1611-1614 (2006).

14) Bontemps S., Sircoglou M., Bouhadir G., Puschmann H., Howard J. A. K., Dyer P. W., Miqueu K., Bourissou D., Chem. Eur. J., 14, 731-740 (2008) .

15) Sircoglou M., Bontemps S., Mercy M., Saffon N., Takahashi M., Bouhadir G., Maron L., Bourissou D., Angew. Chem. Int. Ed., 46, 8583-8586 (2007).

16) Inagaki F., Matsumoto C., Okada Y., Maruyama N., Mukai C., Angew. Chem. Int. Ed., 54, 818-822 (2015).

17) Inagaki F., Nakazawa K., Maeda K., Koseki T., Mukai C., Organometallics, 36, 3005-3008 (2017) .

18) Bourissou's group reported the similar observation between $[\mathrm{Au}(\mathrm{TPB})] \mathrm{Cl}$ and 
$[\mathrm{Au}(\mathrm{TPB})] \mathrm{GaCl}_{4}$ : see, Ref. 12 .

19) Hammett L. P., J. Am. Chem. Soc., 59, 96103 (1937).

20) Hansch C., Leo A., Taft R. W., Chem. Rev., 91, 165-195 (1991).

21) Emslie D. J. H., Cowie B. E., Kolpin K. B., Dalton Trans., 41, 1101-1117 (2012).

22) Dalton D. M., Rappé A. K., Rovis T., Chem. Sci., 4, 2062-2070 (2013).

23) Hashmi A. S. K., Hutchings G. J., Angew. Chem. Int. Ed., 45, 7896-7936 (2006).

24) Gorin D. J., Toste F. D., Nature, 446, 395403 (2007).

25) Fürstner A., Davies P. W., Angew. Chem. Int. Ed., 46, 3410-3449 (2007).

26) Hashmi A. S. K., Chem. Rev., 107, 3180-3211 (2007).

27) Li Z., Brouwer C., He C., Chem. Rev., 108, 3239-3265 (2008).

28) Arcadi A., Chem. Rev., 108, 3266-3325 (2008).

29) Jiménez-Núñez E., Echavarren A. M., Chem. Rev., 108, 3326-3350 (2008).

30) Gorin D. J., Sherry B. D., Toste F. D., Chem. Rev., 108, 3351-3378 (2008).

31) Patil N. T., Yamamoto Y., Chem. Rev., 108, 3395-3442 (2008).

32) Fürstner A., Chem. Soc. Rev., 38, 3208-3221 (2009) .

33) Wang S., Zhang G., Zhang L., Synlett, 692706 (2010).

35) Hashmi A. S. K., Angew. Chem. Int. Ed., 49, 5232-5241 (2010).

36) Krause N., Winter C., Chem. Rev., 111, 19942009 (2011).

37) Fourmy K., Mallet-Ladeira S., Dechy-Cabaret O., Gouygou M., Organometallics, 32, 15711574 (2013).

38) Simonneau A., Jaroschik F., Lesage D., Karanik M., Guillot R., Malacia M., Tabet J.-C., Goddard J.-P., Fensterbank L., Gandon V., Gimbert Y., Chem. Sci., 2, 2417-2422 (2011).

39) Bartolomé C., Ramiro Z., García-Cuadrado D., Pérez-Galán P., Raducan M., Bour C., Echavarren A. M., Espinet P., Organometallics, 29, 951-956 (2010).

40) Cabello N., Jiménez-Núñez E., Buñuel E., Cárdenas D. J., Echavarren A. M., Eur. J. Org. Chem., 4217-4223 (2007).
41) Nieto-Oberhuber C., López S., Muñoz M. P., Cárdenas D. J., Buñuel E., Nevado C., Echavarren A. M., Angew. Chem. Int. Ed., 44, 6146-6148 (2005).

42) Jaimes M. C. B., Rominger F., Pereira M. M., Carrilho R. M. B., Carabineiro S. A. C., Hashmi A. S. K., Chem. Commun., 50, 49374940 (2014).

43) Mézailles N., Ricard L., Gagosz F., Org. Lett., 7, 4133-4136 (2005).

44) Odabachian Y., Gagosz F., Adv. Synth. Catal., 351, 379-386 (2009).

45) Grirrane A., Garcia H., Corma A., Álvarez E., ACS Catal., 1, 1647-1653 (2011).

46) López-Carrillo V., Echavarren A. M., J. Am. Chem. Soc., 132, 9292-9294 (2010).

47) Obradors C., Leboeuf D., Aydin J., Echavarren A. M., Org. Lett., 15, 1576-1579 (2013) .

48) Antoniotti S., Genin E., Michelet V., Genêt J.-P., J. Am. Chem. Soc., 127, 9976-9977 (2005).

49) Alcaide B., Almendros P., Carrascosa R., Torres M. R., Adv. Synth. Catal., 352, 12771283 (2010).

50) Alcaide B., Almendros P., Carrascosa R., Tetrahedron, 68, 9391-9396 (2012).

51) Alcaide B., Almendros P., Carrascosa R., López R., Menéndez M. I., Tetrahedron, 68, 10748-10760 (2012) .

52) Quach R., Furkert D. P., Brimble M. A., Org. Biomol. Chem., 15, 3098-3104 (2017).

53) Matsumoto C., Yamada M., Dong X., Mukai C., Inagaki F., Chem. Lett., 47, 1321-1323 (2018).

54) Fukuda Y., Utimoto K., J. Org. Chem., 56, 3729-3731 (1991).

55) Fukuda Y., Utimoto K., Bull. Chem. Soc. Jpn., 64, 2013-2015 (1991).

56) Mizushima E., Sato K., Hayashi T., Tanaka M., Angew. Chem. Int. Ed., 41, 4563-4565 (2002).

57) Marion N., Ramón R. S., Nolan S. P., J. Am. Chem. Soc., 131, 448-449 (2009).

58) Romero N. A., Klepser B. M., Anderson C. E., Org. Lett., 14, 874-877 (2012).

59) Fernández G. A., Picco A. S., Ceolín M. R., Chopa A. B., Silbestri G. F., Organometallics, 32, 6315-6323 (2013).

60) Czégéni C. E., Papp G., Kathó Á., Joó F., J. 
Mol. Catal. A Chem., 340, 1-8 (2011).

61) Almássy A., Nagy C. E., Bényei A. C., Joó F., Organometallics, 29, 2484-2490 (2010).

62) Xu Y., Hu X., Shao J., Yang G., Wu Y., Zhang Z., Green Chem., 17, 532-537 (2015).

63) Gatto M., Belanzoni P., Belpassi L., Biasiolo L., Del Zotto A., Tarantelli F., Zuccaccia D., ACS Catal., 6, 7363-7376 (2016).

64) Nun P., Ramón R. S., Gaillard S., Nolan S. P., J. Organomet. Chem., 696, 7-11 (2011) .

65) Marion N., Gealageas R., Nolan S. P., Org. Lett., 9, 2653-2656 (2007).

66) Wang W. L., Zheng A. M., Zhao P. Q., Xia C., Li F. W., ACS Catal., 4, 321-327 (2014).

67) Carriedo G. A., López S., Suárez-Suárez S., Presa-Soto D., Presa-Soto A., Eur. J. Inorg. Chem., 9, 1442-1447 (2011).

68) de Fremont P., Singh R., Stevens E. D., Petersen J. L., Nolan S. P., Organometallics, 26, 1376-1385 (2007).
69) Casado R., Contel M., Laguna M., Romero P., Sanz S., J. Am. Chem. Soc., 125, 1192511935 (2003).

70) Sanz S., Jones L. A., Mohr F., Laguna M., Organometallics, 26, 952-957 (2007).

71) Hartman J. W., Hiscox W. C., Jennings P. W., J. Org. Chem., 58, 7613-7614 (1993).

72) Zhu F.-X., Wang W., Li H.-X., J. Am. Chem. Soc., 133, 11632-11640 (2011).

73) Chevallier F., Breit B., Angew. Chem. Int. Ed., 45, 1599-1602 (2006).

74) He H.-T., Qi C.-R., Hu X.-H., Guan Y.-Q., Jiang H.-F., Green Chem., 16, 3729-3733 (2014).

75) Thuong M. B. T., Mann A., Wagner A., Chem. Commun., 48, 434-436 (2012).

76) Inagaki F., Maeda K., Nakazawa K., Mukai C., Eur. J. Org. Chem., 2972-2976 (2018) .

77) Yoshida M., Mizuguchi T., Shishido K., Chem. Eur. J., 18, 15578-15581 (2012). 